\title{
14. DISTRIBUTION OF DIATOMS IN PLIOCENE AND PLEISTOCENE DEPOSITS FROM THE MIDDLE AMERICA TRENCH OFF GUATEMALA ${ }^{1}$
}

\author{
Anastasia P. Jousé, Galina Kh. Kazarina, and Valentina V. Mukhina, P. P. Shirshov Institute of Oceanology, \\ U.S.S.R. Academy of Sciences, Moscow, U.S.S.R.
}

\section{INTRODUCTION}

The diatom assemblages described in this study are from deposits at Sites 494, 495, 496, and 499, located within the area of the Middle America Trench, Guatemala transect. Hole 495 was drilled on the Cocos Plate, on the seaward slope of the Middle America Trench; Hole 499 was drilled directly on the trench bottom; and Holes 494 and 496 were drilled in the lower and middle parts of the Guatemala continental slope. This transect of sites across the trench enables us to correlate deposits from the oceanic plate to the continental margin.

In general, we investigated the diatoms found in Pleistocene and Pliocene sections of all the sites. Our investigation of diatoms of Site 495 was broader and included diatoms from the Pleistocene to the lower Mioceneour aim being to obtain comprehensive information about the composition and distribution of diatoms in the Neogene of the region concerned. The section is unique in its completeness and is essential to this account.

All sites located on the trench bottom and on the continental slope penetrated thick beds of Pleistocene sediments $(180-200 \mathrm{~m})$; only small portions fell within the lower Pleistocene. Pliocene sediments are poor in diatoms and not thick. On the whole, Pliocene and Pleistocene sediments are characterized by poor diatom remains as a result of terrigenous-volcanogenic dilution.

Our analysis of the taxonomy and the ecology of the Pliocene and Pleistocene diatom flora is aimed at establishing the stratigraphy of deposits drilled during Leg 67. Deposits penetrated by drilling during DSDP Leg 67 are stratigraphically subdivided on the basis of L. Burckle's diatom stratigraphy (Burckle, 1972; Burckle and Opdyke, 1977) and modified by the data of subsequent investigations (Kazarina, 1975, 1978; Burckle, Trainer, 1979). The changes introduced into Burckle's (1972) scale are minor and consist of the following: the Nitzschia reinholdii Zone (1.8 m.y.-630,000 yr.) in Burckle's scale is replaced by a stratigraphically equivalent zone, the Nitzschia fossilis Zone, and in the Pseudoeunotia doliolus Zone (700,000 yr.-present day) additional units with Coscinodiscus pseudoincertus and those with Coscinodiscus nodulifer were distinguished.

In addition to these species and zones, we concentrated on the stratigraphic distribution of some particu-

\footnotetext{
${ }^{1}$ Aubouin, J., von Huene, R., et al., Init. Repts. DSDP, 67: Washington (U.S. Govt, Printing Office).
}

lar species: Thaslassiosira sp. 1, Thalassiosira sp. 2, Thalassiosira plicata, Thalassiosira leptopus var. ellipti$\mathrm{ca}$, Coscinodiscus pseudoincertus, the vertical ranges of which can be subsequently used for stratigraphic purposes.

Despite a relatively uniform Pleistocene flora of diatoms, certain changes in their composition at various time intervals were recognized. Unfortunately, we have no materials available that would allow us to correlate these changes on an absolute-age basis. Nevertheless, the available data clearly show their succession in the Leg 67 sections.

The Pleistocene diatom assemblages at Sites 494, 496, and 499 are heterogeneous. Along with marine species, there are brackish- and fresh-water, mostly benthic, species of a sublittoral zone now found in the Pleistocene deposits in the Trench floor and on the continental slope, confirming their turbiditic origin.

Especially noteworthy is the abundance of diatoms occurring throughout the entire Pleistocene section of the Leg 67 sites.

\section{SITE 494 (HOLES 494, 494A)}

Holes 494 and 494A (Fig. 1, Table 1) were drilled on the lower slope of the Middle America Trench (their location: Hole $494-12^{\circ} 43.00^{\prime} \mathrm{N}, 90^{\circ} 55.97^{\prime} \mathrm{W}$; Hole $\left.494 \mathrm{~A}-12^{\circ} 43.01^{\prime} \mathrm{N} ; 90^{\circ} 55.97^{\prime} \mathrm{W}\right)$. The holes penetrated a total thickness of 366.5 meters. The age of the base of the section has been determined as Late Cretaceous by foraminiferal fauna (see Site 494 report and Thompson, this volume).

We studied diatoms in the Pliocene/Pleistocene part of the section (Cores 1-20, $213 \mathrm{~m}$ ). Unfortunately, poor core recovery did not allow us to analyze the sequence at regular intervals, and, correspondingly, many details of changes in the diatom flora are not entirely clear. This is especially the case, given that diatoms are not abundant in the sediments that we do have. A certain increase of diatomic valve concentrations is observed episodically, mostly in the upper seven cores. Below, diatoms are represented by somewhat impoverished assemblages relative to their absolute numbers and to their diversity. On the whole, however, the diatom frustules are well preserved, and only in Sample 494A-1-3, 40-42 cm did we observe valves with obvious traces of dissolution.

At the base of the section a unit is distinguished (Sections 494A-20-3 to 494A-18-4), the sediments of which are relatively poor in the diatom assemblage typical of the lower Pliocene of the World Ocean tropical latitudes: Nitzschia jouseae, Thalassiosira convexa, Bogorovia me- 


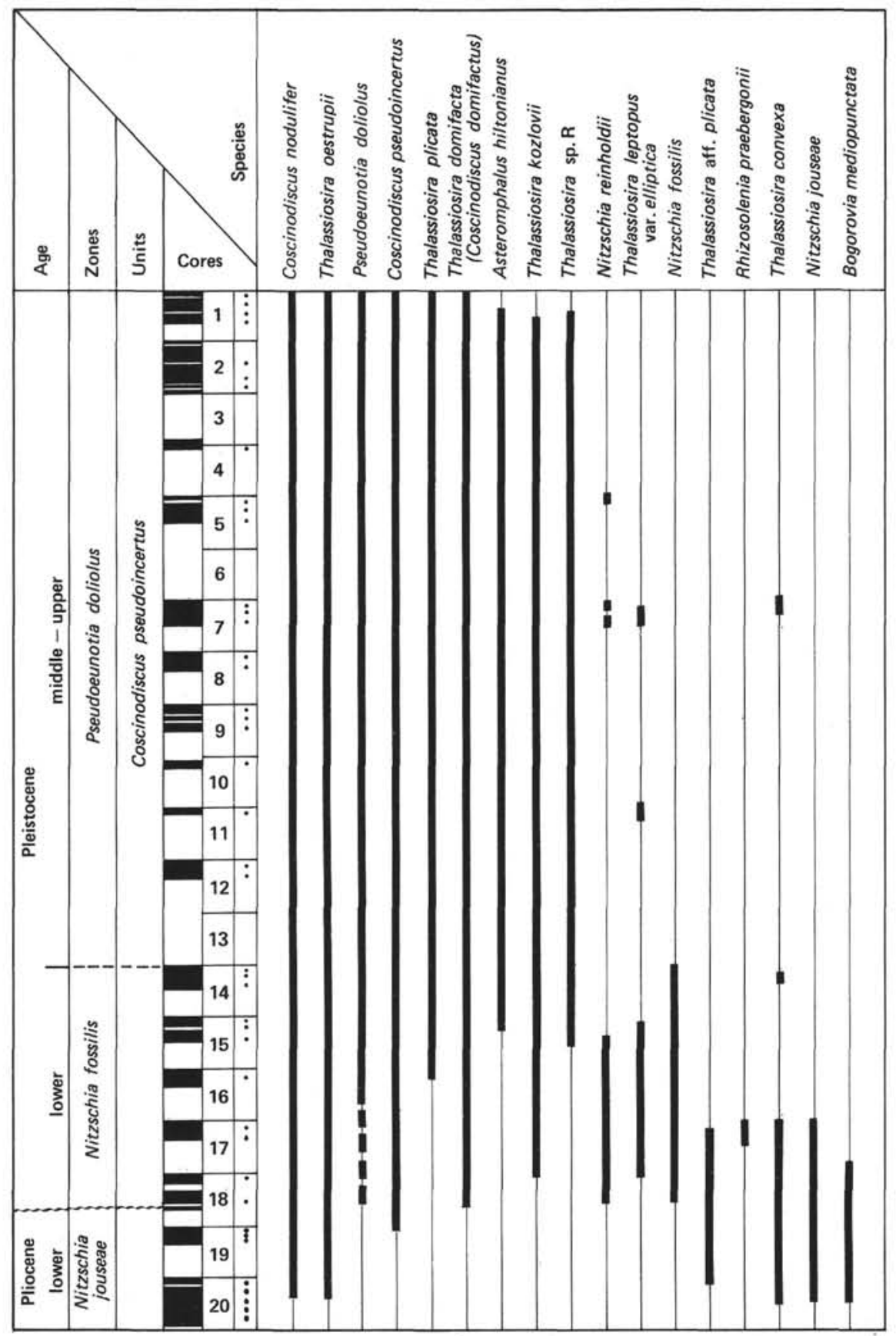

Figure 1. Ranges of selected species of diatoms from Site 494. (In the Cores columns of Figs. $1-4$, shaded intervals represent the amount of sediments recovered in each core; dots indicate the sections of each core that were studied.)

diopunctata. The presence of Nitzschia jouseae in the assemblage allows us to attribute the interval (494A20-3 to 494A-18-4) to the late middle Pliocene zone.

The middle Pliocene deposits are overlain by a thick (181 m) pile of Pleistocene deposits (494A-18-4 to 494A1-1); upper Pliocene sediments corresponding to the Rhizosolenia praebergonii Zone are completely missing in the section. The Pleistocene was identified by the presence of specimens of the index species Pseudoeunotia doliolus and Rhizosolenia matuyamai found in Section 494A-18-4. Despite the fact that higher up in the section
(494A-18-1 to 494A-17-1) Pseudoeunotia doliolus is missing, the presence of Thalassiosira leptopus var. elliptica confirms that the sediments are Pleistocene. Previously, this species was identified by us in Pleistocene deposits only. Rather numerous Thalassiosira convexa, Nitzschia jouseae, and Bogorovia mediopunctata observed in the interval between Section 494A-18-4 and Section 494A17-1 are likely in the secondary bedding.

Beginning from Section 494A-16-1, old redeposited forms are, as a rule, missing in diatom assemblages; the changes in the species composition and sequence are 
Table 1. Coded values for diatom abundances in samples from Hole 494A.

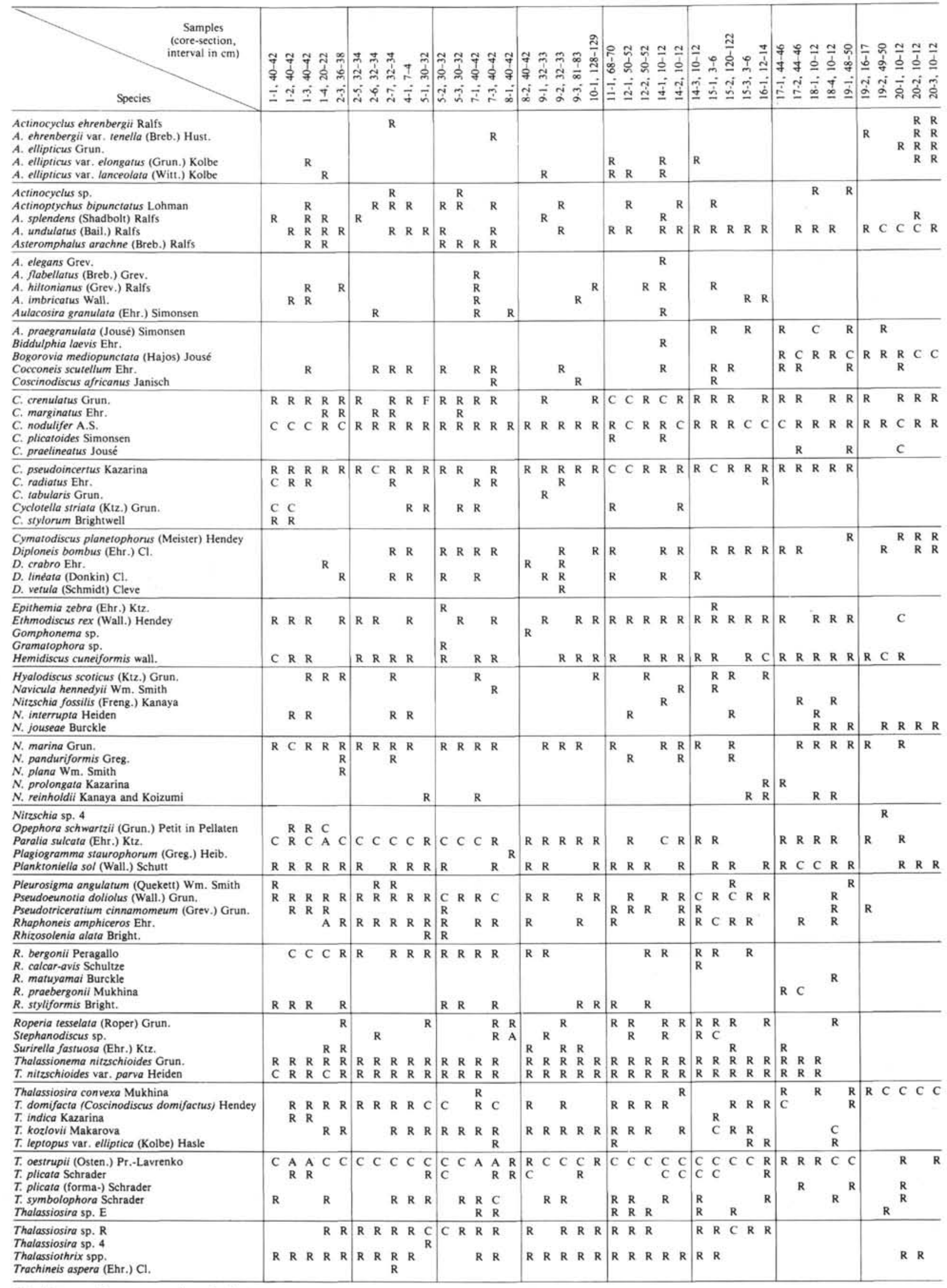

Note: $\mathbf{R}=$ rare; $\mathrm{C}=$ common; $\mathrm{A}=$ abundant. 
quite regular and similar to those established previously in the tropical area of the Indian Ocean (Kazarina, 1978). These changes allow us to single out two zones in the section: Nitzschia fossilis (494A-18-4 to 494A-14-1) of the lower Pleistocene and Pseudoeunotia doliolus (494A14-1) of the middle upper Pleistocene. The Nitzschia fossilis Zone appears to be represented in the key section not fully, but only by its upper part. Absence of the silicoflagellate Mesocena elliptica in sediments of the zone seems unusual. The drawing of the upper boundary of the Nitzschia fossilis zone is conditional, as the index species is represented by a single specimen.

The Pseudoeunotia doliolus Zone is characterized by the richest assemblages, the nucleus of which is composed of recent oceanic species: Coscinodiscus nodulifer, Thalassiosira oestrupii, Rhizosolenia bergonii, Nitzschia marina, etc. Sublittoral, slightly brackish-water species are abundant in this interval: Stephanodiscus $\mathrm{sp}$. (Sample 494A-18-1, 40-42 cm), Raphoneis amphiceros, Surirella fastuosa, Cocconeis scutellum, Diploneis bombus, D. crabro, D. lineata, and Cyclotella striata. For instance, in Section 494A-8-2 the content of the Stephanodiscus sp. species can be described by the words "in mass."

Going upwards within this zone the assemblage successively loses: Thalassiosira leptopus var. elliptica, Nitzschia reinholdii, etc. Coscinodiscus pseudoincertus is common up to the top of the section, showing that the youngest deposits are missing in it. This conclusion is based on the assumption that distribution of Coscinodiscus pseudoincertus in the Pacific Ocean is similar to that of the given species in the Indian Ocean, where it became extinct in the uppermost parts of the upper Pleistocene (Kazarina, 1978).

\section{SITE 495}

Site 495 (Fig. 2, Table 2) was drilled on the Cocos Plate on the outer slope of the Middle America Trench $\left(12^{\circ} 29.78^{\prime} \mathrm{N} ; 91^{\circ} 02.26^{\prime} \mathrm{W}\right)$ at a depth of 4140 meters. The drilling penetrated 446.5 meters of deposits ranging from lower Miocene to upper Pleistocene inclusive, a continuous section with very good core recovery. We studied diatoms and silicoflagellates from 122 samples. Most of the cores contained a complete set of sections, except for Cores 8, 11, 19.

The stratigraphic thicknesses based on diatom age assignments of Site 495 sediments coincides with the stratigraphy established by fauna of radiolarians, foraminifers, and nannoplankton (see Westberg and Riedel, this volume).

A thick unit of carbonate sediments with an admixture of lower and middle Miocene diatoms and radiolarians rests at the base of the section. Siliceous organisms are badly preserved and not diverse. Substitution of carbonate oozes by siliceous diatom-radiolarian ones takes place at the level of Sample 495-19-6, 30-32 cm. The sediments in the interval between Section 495-18-4 and Sample 495-12-4, 60-61 cm have such an abundance of diatoms that they can be referred to as diatom oozes.

One hundred and twenty species of diatoms and about 20 species of silicoflagellates were identified throughout the section at Site 495. Some individuals remained un- identified, especially among Thalassiosira and Actinocyclus. Six large evolutionary stages in diatom development have been suggested during the time of formation of deposits penetrated at Hole 495. Layers and zones corresponding to middle and upper Miocene, lower and upper Pliocene, and Pleistocene are distinguished from bottom to top. Beginning with Sample 495-3-1, 75-77 $\mathrm{cm}$, the diatom composition indicates that a part of upper Pleistocene and Holocene sediments are missing, in agreement with the radiolarian zonations at this site (see Westberg and Riedel, this volume).

\section{Lower Miocene Interval (Sections 495-26-5 to 495-25-1)}

These are characterized by a rather peculiar complex of diatoms with prevailing Cestodiscus (C. kugleri, Cestodiscus spp.), Synedra jouseana, Coscinodiscus lewisianus, C. marginatus var. antiqua, Annellus californicus, Coscinodiscus vetustissimus, and a peculiar small form of Actinocyclus ingens that is sporadic. Among silicoflagellates observed are: Corbisema triacantha, Dictyocha ausonia, D. deflandrei, Mesocena elliptica.

An identical assemblage of diatoms occurs at the base of Holes 499 and 499B. Bukry (1980) found a similar composition of diatoms and silicoflagellates in sediments at Sites 415 and 416, DSDP Leg 50, near the north-western shore of Africa. In the central part of the Pacific Ocean, at Sites 66 and 65 (DSDP Leg 7) and at Site 166, DSDP Leg 17, the lower Miocene diatom flora is also similar (E. P. Rodionova, personal communication, 1980).

\section{Middle Miocene Interval (Sections 495-24-8 to 495-18-7)}

Coccolith oozes dominate this interval, and in the lower part diatoms are practically absent in sediments (Sections 495-24-8 to 495-21-3); only rare valves of $\mathrm{Acti}$ nocyclus ingens were sometimes observed.

The amount of diatoms increases appreciably in the upper part of middle Miocene sediments, however, the entire middle Miocene was characterized by a low yield of diatoms and radiolarians. This scarcity results from unfavorable conditions for their development and considerable dilution. The following are most representative in the composition of a rich assemblage: Coscinodiscus plicatus, Denticuliopsis lauta, Coscinodiscus tabularis var. egregius, Actinocyclus ellipticus var. javanicus, var. moronensis, Bogorovia paleacea, Thalassiosira aff. leptopus. The end of the middle Miocene is characterized by a gradual increase of Coscinodiscus marginatus var. antiqua that becomes abundant at the base of upper Miocene sediments. The silicoflagellate flora is composed of Distephanus crux, Dictyocha deflandrei, and Ebriopsis antiqua of the Ebriaceae family.

We suggest singling out the Coscinodiscus plicatus unit for this part of the section. It is possible that subsequent investigations will enable us to distinguish a zone of this name for the upper part of the middle Miocene of the tropical area of the World Ocean.

\section{Upper Miocene Interval (Sections 495-18-7 to 495-14-5)}

The upper Miocene at Site 495 is characterized by an exceptional abundance and diversity of diatoms and silicoflagellates. The accumulation of diatom-radiolarian 


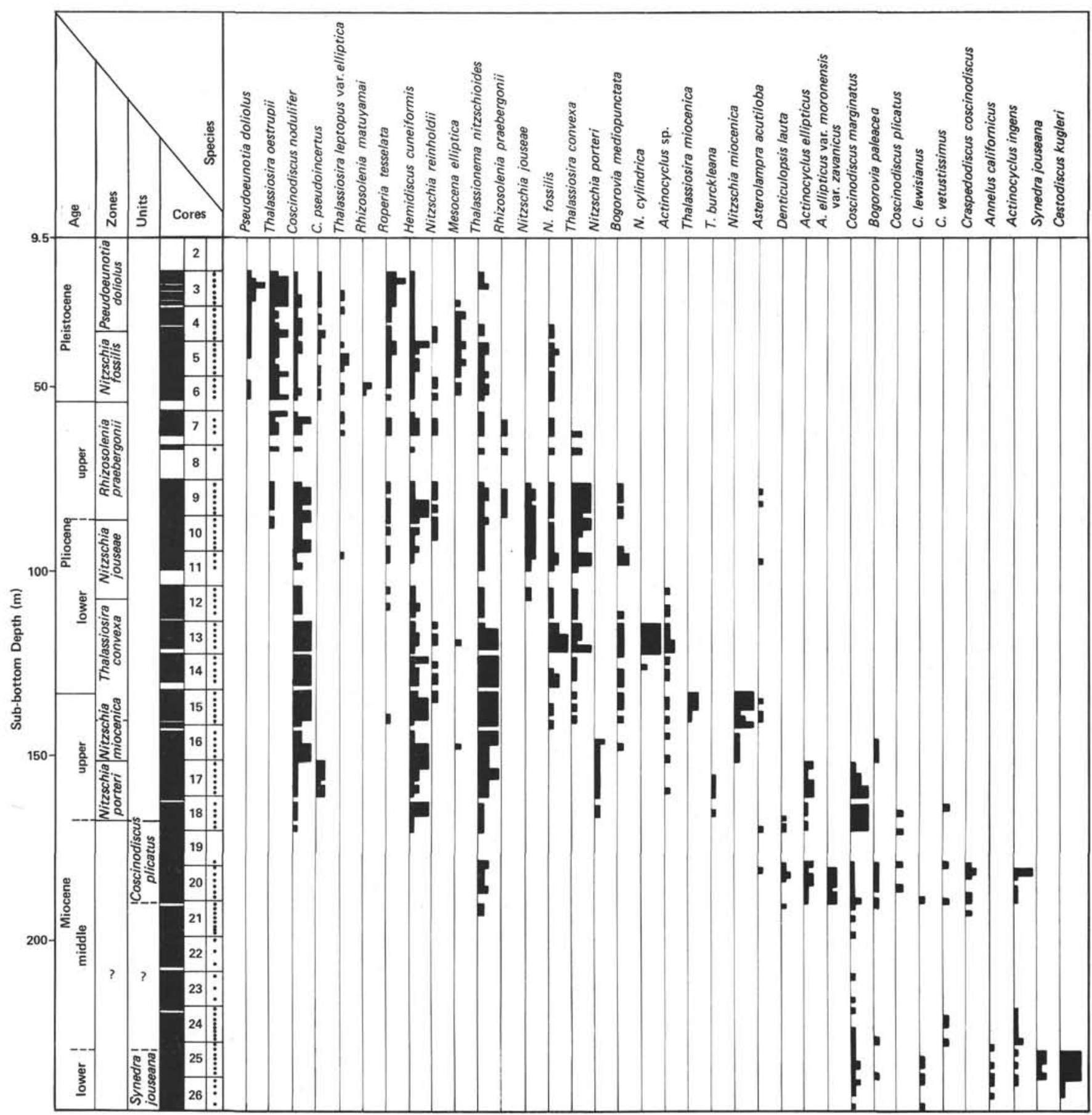

Figure 2. Ranges of selected species of diatoms from Site 495. (See Fig. 1 for an explanation of the Cores columns; bar thickness indicates relative abundance.)

sediments in the late Miocene occurred under conditions of a very rich supply of siliceous organisms to the bottom, dilution by terrigenous and organic sediment being insignificant. The upwelling zone and rise of deep waters in the near seashore area may have affected sedimentation at Site 495 during this time. Lower temperatures of the upwelling zones promoted development of neritic diatoms that are more cold-water by nature. Noteworthy is a very abrupt increase of cold-water Coscinodiscus marginatus content in sediments at that period.
Upper Miocene deposits are well subdivided into two stratigraphic zones: Nitzschia porteri in the interval between Core 17, Section 5 and Core 16, Section 5 and Nitzschia miocenica in the interval between Core 16, Section 1 and Core 15, Section 1. This distinction confirms the zonation suggested by Burckle (1972) and observed in the Indian Ocean by Kazarina (1978) and Schrader (1974).

In the diatom assemblage of the Nitzschia porteri zone, the tropical species Coscinodiscus nodulifer and 
Hemidiscus cuneiformis are abundant. The lower boundaries of both species pass close to the middle upper Miocene boundary. Noteworthy is that the upper boundary of cold-water Coscinodiscus marginatus occurs very near the lower boundary of tropical $C$. nodulifer. In substituting for one another, both species testify to a progressive warming of waters from the beginning of the late Miocene. The assemblage of this zone is characterized by Thalassiosira burckliana and Bogorovia paleacea - the upper boundary of those species lies within this zone.

The next upper Miocene zone, Nitzschia miocenica, has a small stratigraphic volume. It is situated within Sections 495-16-6 to 495-15-1. Mass accumulations of the zonal species are peculiar to the upper part of that interval. The second zonal species of the upper Miocene, Thalassiosira miocenica, occupies the same inter$\mathrm{val}$ as $N$. miocenica, but its concentration in sediments is much less. The upper boundaries of both species determine the position of the Miocene/Pliocene boundary, which according to Burckle (1972) corresponds to the Gilbert/Epoch 5 boundary (absolute age date of 5.1 m.y.).

The diatom assemblage of the Nitzschia miocenica Zone includes Thalassiosira miocenica, Asterolampra acutiloba, Cussia lancettula, and Raphoneis lancettula. One of the most remarkable peculiarities of late Miocene diatom flora is very high diversity of Thalassiosira. This is the first maximum since the lower Miocene, where, just like in middle Miocene, Thalassiosira were missing. The late Miocene stage in the Cocos Plate region is characterized by high numbers of most diverse forms of Thalassionema nitzschioides and as many as three species of Thalassiothrix. Their abundance may have been determined by conditions in the near-shore upwelling zone.

In concluding our discussion of the upper Miocene zones at Site 495, we would like to note that Roperia tesselata, Nitzschia reinholdii, and Thalassiosira convexa appear for the first time near the Miocene/Pliocene boundary. The first species remains preserved up till the present, the two others became extinct by Pleistocene.

\section{Pliocene Interval}

These deposits occur in the interval from Section 49514-5 to Sample 495-7-1, 40-42 cm. Their lower boundaries are established by extinction of two upper Miocene species: Nitzschia miocenica and Thalassiosira miocenica. The upper boundaries are drawn according to the first appearance of Pseudoeunotia doliolus. Extinction of Rhizosolenia praebergonii, an index species of the upper Pliocene zone, takes place near this boundary (Mukhina, 1971, Burckle, 1972). As Burckle (1972) and Saito, Burckle, and Hays (1975) believe, extinction of Rhizosolenia praebergonii took place at the very beginning of the Pleistocene, directly after the Olduvai Paleomagnetic Event (1.63 Ma).

We draw the boundary between the lower and upper Pliocene at Core 9, Section 6, 40-42 cm). An abundance of Thalassiosira convexa characterizes the deposits between Sections 495-11-3 and 495-9-3. Above the Thalas- siosira convexa Zone the lower Pliocene Nitzschia jouseae Zone is well identified.

Lower Pliocene diatomaceous sediments are as rich in diatom remains as the upper Miocene deposits. Their composition retains high numbers of Coscinodiscus nodulifer, Hemidiscus cuneiformis, Thalassionema nitzschioides and Thalassiothrix spp., together with numerous new species peculiar to the Pliocene.

The lower Pliocene flora is characterized by Nitzschia fossilis and Nitzschia cylindrica. As opposed to the late Pliocene flora, that of the early Pliocene is more diverse, with numerous species that are now extinct: Nitzschia sicula, Bogorovia mediopunctata, and others. Diatom assemblages indicate that the late Miocene and early Pliocene environment in the Guatemala Rise region was one of upwelling.

The late Pliocene flora differs insignificantly from the flora of the recent tropical belt of the Pacific Ocean. Extinct Rhizosolenia praebergonii disappears above the Pliocene/Pleistocene boundary. The flora, on the whole, is characterized by diverse Thalassiosira that require further studies. Thalassiosira leptopus var. elliptica appeared during the late Pliocene and persisted to the upper boundary of the middle Pleistocene. The maximum abundance of Thalassiosira oestrupii occurred at the end of Pliocene to the beginning of the Pleistocene. The general decrease of diatom concentration at the end of the Pliocene probably resulted from conditions unfavorable to their development.

The Pleistocene cover in the section of Site 495 occupies the interval between Sections 495-6-4, to 495-1-1 to the sediment/water interface, a total thickness of about 60 meters. The lower boundary is drawn according to extinction of Rhizosolenia praebergonii and appearance of Pseudoeunotia doliolus. The analysis of diatoms enables us to assign the lower part of the Pleistocene to the Nitzschia fossilis Zone (Section 495-6-4 to $495-4-3,30-32 \mathrm{~cm}$ ) established for the first time by Kazarina $(1975,1978)$. Burckle and Opdyke (1977) distinguished the Nitzschia reinholdii zone in the same interval. In our section both species occur in parallel, and become extinct simultaneously (at the level of Sample 495-4-4, 30-32 cm). The Nitzschia fossilis Zone contains Mesocena elliptica, Rhizosolenia matuyamai (Burckle), and Coscinodiscus nodulifer $\mathrm{f}$. cyclopus. Above the Nitzschia fossilis Zone a diatom assemblage is characterized by the presence of Coscinodiscus pseudoincertus, which becomes extinct (after Kazarina, 1978) before reaching the upper boundary of the Pleistocene. Worth attention is that $C$. pseudoincertus appeared for the first time in the section at the base of the upper Miocene, and then reappeared at the lower boundary of the Pleistocene. High numbers of three subtropical species are peculiar to this layer: Roperia tesselata, Thalassiosira oestrupii, and Pseudoeunotia doliolus.

The species composition of diatom assemblages changed during the Pleistocene from a more oceanic and warm-water (tropical) assemblage to a cooler-water and more near-shore (neritic) one. A similar pattern of diatom assemblage changes in the Pleistocene was recorded for sediments at Site 425 , Leg 54 and in cores 
from Leg 8 of the Research Vessel Dmitry Mendeleev (V. V. Mukhina, personal communication, 1980). So this tendency can be recognized in other parts of the equatorial Pacific Ocean. Peak abundances of Roperia tesselata are probably related to cooler climatic periods. On the paleomagnetic scale they correspond to early Brunhes (Burckle, 1977).

In conclusion, we would like to call attention to the fact that many species underwent extremely significant morphological changes during their long existence: Coscinodiscus nodulifer, Thalassiosira oestrupii, Hemidiscus cuneiformis, Coscinodiscus marginatus, and so on. Special morphological forms appeared because of evolutionary changes that were influenced by fluctuating environmental conditions.

\section{SITE 496}

Site 496 (Fig. 3, Table 3) is located on the slope of the Middle America Trench $\left(13^{\circ} 03.82^{\prime} \mathrm{N}, 90^{\circ} 47.71^{\prime} \mathrm{W}\right)$ at a water depth of 2049 meters. Hole 496 was drilled to a sub-bottom depth of 378 meters. The purpose of drilling at this site was to examine diatoms in Pliocene/Pleistocene deposits.

Uneven selection of core samples and often extremely poor assemblages make stratigraphic assignment of deposits difficult and introduce some uncertainties into establishing the time boundaries.

We studied diatoms from 85 samples of the upper unit of the hole: from Core 1, Section $1,30-32 \mathrm{~cm}$ to Core 27, Section 2, 50-52 cm. The diatom flora is, on the whole, well preserved. Redeposition of old forms into Quaternary sediments is insignificant, except for Sample 496-25-3, 103-105 cm.

The study of diatoms in Miocene deposits of Site 496 revealed the presence of Nitzschia miocenica and Thalassiosira miocenica in Sample 496-27-2, 50-52 cm, enabling us to attribute it to the upper Miocene upper Nitzschia miocenica Zone. Our study does not include the older deposits at this site.

Higher up the section, in Samples 496-26-6, 40-42 cm . to $496-26-3,30-32 \mathrm{~cm}$, the sediments are practically devoid of diatoms. Determination of the age of these deposits is difficult. The Pliocene deposits at Site 496 are fixed only in one sample, 496-26-1, 30-32 cm. The presence of Rhizosolenia praebergonii, Thalassiosira convexa, Nitzschia jouseae, and Bogorovia mediopunctata in the assemblage dates the sediments as late Pliocene; we may attribute them to the lowermost parts of the Rhizosolenia praebergonii Zone. Thus at Site 496 Pliocene deposits are characterized by incomplete diatom assemblages; there are no beds corresponding to the Thalassiosira convexa, Nitzschia jouseae, or the uppermost parts of the Rhizosolenia praebergonii Zones.

Higher up in the section we found Pleistocene deposits. In Sample 496-24-4, 30-32 cm the assemblage contians a form typical of the Pleistocene, Pseudoeunotia doliolus. Its association with Rhizosolenia praebergonii allows us to speak of the early Pleistocene age of the deposits. Worthy of attention is the abundance of the Pliocene species Thalassiosira convexa, presumably redeposited in Sample 496-25-3, 103-105 cm. The silicoflag- ellate Mesocena elliptica was identified in the overlying interval of the site (Samples 496-24-4, 70-72 cm to 496$22-1,50-52 \mathrm{~cm}$ ). Rhizosolenia matuyamai was found in Sample 496-23-2, 43-44 cm, allowing us to correlate sediments of that interval to the Jaramillo Event in the paleomagnetic scale (Jousé, Mukhina, 1973; Burckle, Hammond, Seyb, 1978). In Sample 496-21-8, 75-77 cm we observed an increase of number and size of valves of the Rhizosolenia styliformis; we have observed a similar trend in lower Pleistocene deposits of the tropical Indian Ocean. At the level of Sample 496-21-2, 16-17 cm Nitzschia fossilis disappears from the assemblage; therefore the Pleistocene deposits extend from Core 25, Section $4,30-32 \mathrm{~cm}$, to Core 21 , Section $2,16-17 \mathrm{~cm}$, all belonging to the Nitzschia fossilis Zone.

Higher up in the section the relatively uniform diatom assemblages belong to the Pseudoeunotia doliolus Zone of the middle upper Pleistocene (Samples 49621-1, 16-17 cm to 496-1-1, 30-32 cm. Presence of the key species Coscinodiscus pseudoincertus in Site 496 sediments allows us to consider the unit, Core 1, Section $1,30-32 \mathrm{~cm}$, as the Coscinodiscus pseudoincertus Subzone and to assume that beds corresponding to the uppermost Pleistocene and the Holocene are absent. Despite the seeming monotony of the floral composition, the unit has some unique features. In the intervals of Samples 496-21-1, 16-17 cm, 496-20-2, 71-72 cm, 496$19-4,77-78 \mathrm{~cm}$, and $496-19-1,77-78 \mathrm{~cm}$ the assemblage is characterized by mass occurrence of Thalassiosira oestrupi. In Sample 496-20-1, 71-72 cm an increase in relative abundance of Roperia tesselata var. may have been caused by a cooler climate in the period corresponding to 0.61 to $0.62 \mathrm{Ma}$ (Burckle, 1977). A considerable increase in diversity and quantity of benthic species including Diploneis bombus, D. lineata, and Stephanodiscus astraea is characteristic of this interval. Disappearance of some peculiar species was recorded: Nitzschia reinholdii (Sample 496-19-2, 77-78 cm), Thalassiosira leptopus var. elliptica (Sample 496-12-5, 60-62 $\mathrm{cm}$ ), and Thalassiosira plicata (Sample 496-3-1, 30-32 $\mathrm{cm})$. The interval from Core 3 , Section $5,30-32 \mathrm{~cm}$ to Core 1 , Section $3,30-32 \mathrm{~cm}$ is characterized by an abundance of the tropical species Coscinodiscus nodulifer.

\section{SITE 499}

Site 499 (Fig. 4, Table 4) is located in the axis of the Middle America Trench at $120^{\circ} 40.26^{\prime} \mathrm{N}, 90^{\circ} 56.69^{\prime} \mathrm{W}$ at a water depth of 6105 meters and $20 \mathrm{~km}$ to the northnorth-east of Site 495 . Hole 499 penetrated 229 meters of deposits, two thirds of which are Pleistocene sediments. Cores were sampled at large intervals, so the boundaries of separate beds are conditional. Diatoms were studied in 42 samples from Sections 499-1-1 to 499-25-3.

The upper 19 cores contain an assemblage of diatoms unique to the Pleistocene. After a considerable hiatus (Core 20 is missing), late Pliocene diatoms were identified in samples from Core 22.

During the Pleistocene and late Pliocene, turbidites, rich in volcanogenic material, accumulated in the Middle America Trench. These sediments are very poor in 


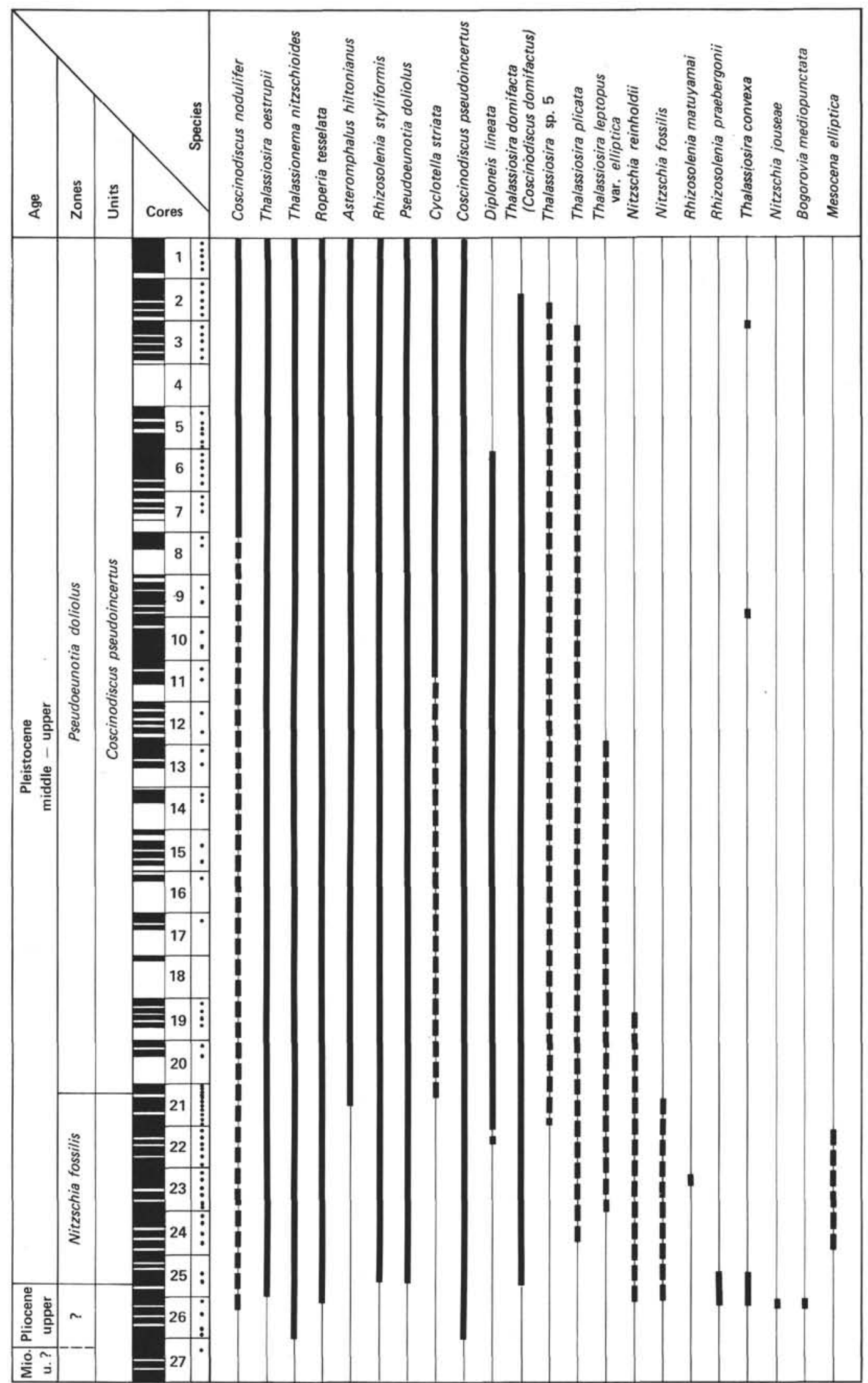

Figure 3. Ranges of selected species of diatoms from Site 496. (See Fig. 1 for an explanation of the symbols.) 


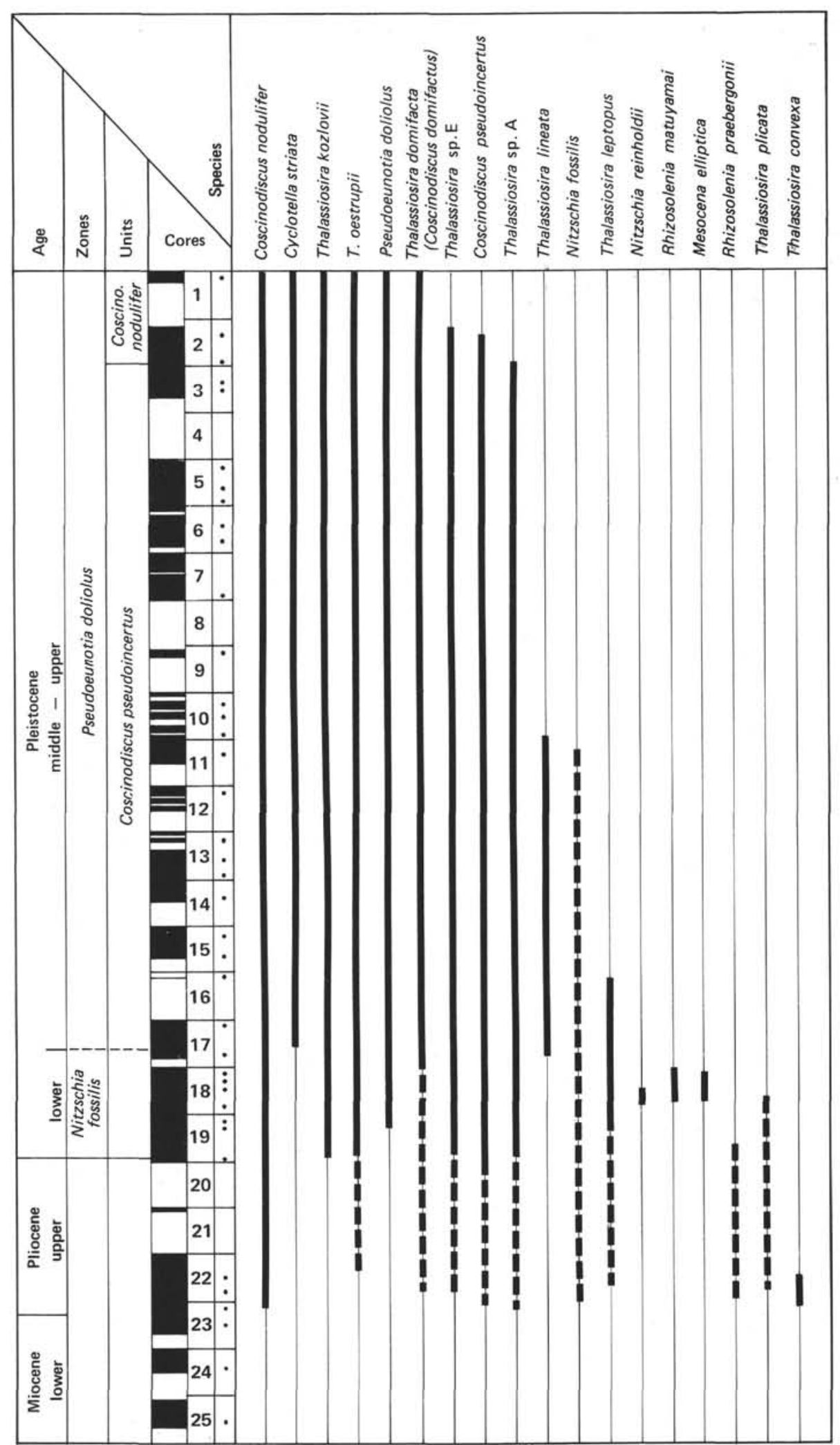

Figure 4. Ranges of selected species of diatoms from Site 499. (See Fig. 1 for an explanation of the symbols.) 
Table 4. Coded values for diatom abundances in samples from Site 499.

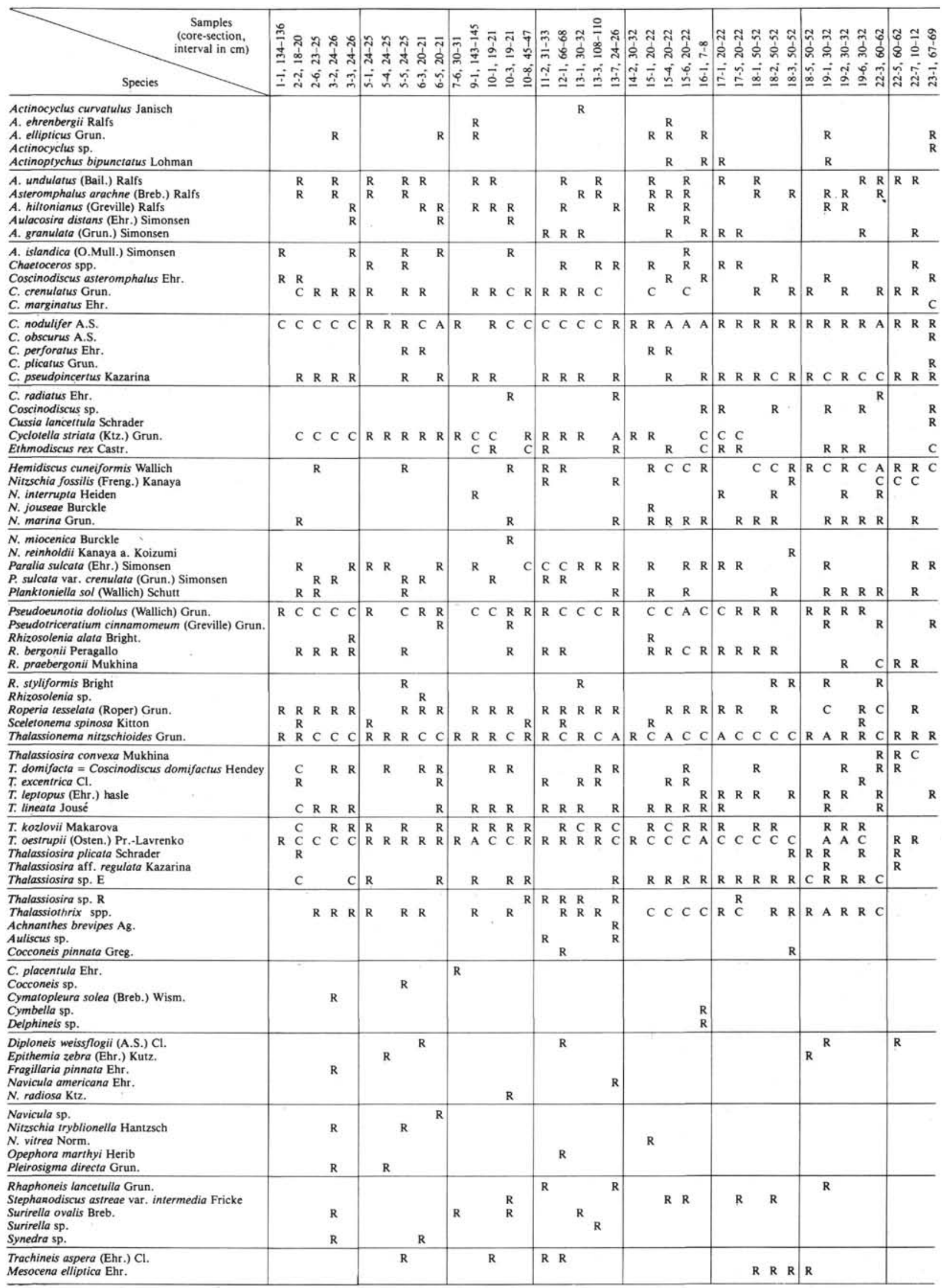

Note: $\mathrm{R}=$ rare; $\mathrm{C}=$ common; $\mathrm{A}=$ abundant. Fresh-water and benthic species are listed beginning with Achnanthes brevipes Ag. Mesocena elliptica Ehr. is a silicoflagellate. 
diatom remains throughout almost all the section. Only below Core 15, Section 4 do their numbers considerably increase, at the expense of some oceanic species of diatoms. The lower boundary of Pleistocene deposits is at the level of Section 499-19-6. This section contains a diatom assemblage typical of the Pleistocene, though Pseudoeunotia doliolus is absent.

Diatoms in Core 22, Sections 3, 5, 6, and 7 are represented by an assemblage of species characteristic of the late Pliocene: Rhizosolenia praebergonii, Nitzschia fossilis, and Thalassiosira convexa, as well as other rarer species: Coscinodiscus nodulifer, Hemidiscus cuneiformis, Roperia tesselata, and Thalassiosira oestrupii. High numbers of the tropical species $R$. praebergonii and $N$. fossilis testify to high temperatures of the surface layer of waters in the late Pliocene. Presence of Rhizosolenia praebergonii in the diatom composition of this unit enables us to attribute the deposits of Core 22, Sections 3, 5, and 7 to the upper Pliocene zone of the same name (Mukhina, 1971, Burckle, 1972, Kazarina, 1978). It appears that the drilling did not penetrate the entire zone in the section.

Below Core 22 are carbonates rich in nannoplankton and foraminifers but containing only poorly preserved diatoms and radiolarians. We did not carry out a detailed examination of this part of the section, however, a cursory look at the samples showed diatom assemblages representative of the lower Miocene flora. Its analogue is an assemblage recognized at the base of the Site 495 section. The assemblage contains: Cestodiscus kugleri, Cestodiscus sp., Synedra jouseana, Coscinodiscus lewisianus, and C. marginatus var. antiquus.

Despite the extension of the range curves (Fig. 4), the tropical Pleistocene assemblages allow us to distinguish a unit between Sections 499-19-6 and 499-17-5. The diatom assemblage of this layer contains extinct species: Thalassiosira plicata, Rhizosolenia matuyamai, Nitzschia reinholdii, and Mesocena elliptica (silicoflagellates). The same components of the flora, as well as Nitzschia fossilis, characterize the early Pleistocene flora of Site 495 (Fig. 2). No Nitzschia fossilis was recognized at Site 499, all accompanying species, however, being present. The diatom assemblage under consideration with the index species Nitzschia fossilis corresponds to the lower Pleistocene zone. The data on radiolarians obtained during Leg 67 speak of the presence of Anthocystidium angulare in this unit, a species peculiar to the lowermost Quaternary (see Westberg and Reidel, this volume).

The entire upper subdivision of the Pleistocene section has a uniform diatom composition in Core 17, Section 5 and above. Differences are mostly in quantity; an appreciably higher concentration of diatoms is observed in Core 17, Section 5 through Core 15 , Section 1 directly overlying a lower Pleistocene layer. Two oceanic species representative of tropics are in abundance in this layer: Coscinodiscus nodulifer and Hemidiscus cuneiformis.

The most striking peculiarity of the diatom assemblage is the presence of Cyclotella striata, which is abundant in some samples. This brackish-water species inhabits low salinity areas of the seas, such as river mouths, and is also frequently recognized in sediments of upwell- ing zones (Jousé, 1972; Mukhina, 1974; Schuette and Schrader, 1979). Deposits of the Middle America Trench are, therefore, characterized by the presence of autochthonous species transported in turbidity flows. Along with Cyclotella striata are only a few individuals of the brackish-water genus Aulacosira. When judged by distribution of Cyclotella striata along the section at Site 499 , we may assume that accumulation of turbidites is unique to the period since the end of the early Pleistocene.

Almost all the species of marine diatom flora occurring above Core 19, Section 6 reach the upper boundary of the Pleistocene, except for Coscinodiscus pseudoincertus, Thalassiosira leptopus, and probably Thalassiosira domifacta, Thalassiosira sp. E, Thalassiosira sp. R.

Observations of distribution of Coscinodiscus pseudoincertus in Pleistocene sediments of the Indian Ocean convince us that this species became extinct before the Pleistocene/Holocene boundary (Kazarina, 1978). This range serves as a basis for distinguishing a unit with Coscinodiscus pseudoincertus. The stratigraphic volume of Thalassiosira leptopus is not quite clear yet, neither it is known whether this species is extinct or living now. In the unit concerned it is not present above Section 499-161. The same peculiarities of distribution of the species were observed at Site 495 .

Diatom floras, therefore, enable us to stratigraphically subdivide Pleistocene deposits in tropical regions, as has been done for deposits of the boreal area, where zones of lower, middle and upper Pleistocene are well distinguished by the composition of diatom assemblages (Jousé, 1971; Koizumi, 1975; Harper, 1980). The analysis of the available material reveals a certain regularity in distribution of diatoms throughout a greater part of the Pleistocene. The maximum transportation of sediments from the slopes appeared to proceed in middle and late Pleistocene, when the pile, almost 160 meters thick, accumulated.

\section{CONCLUSIONS}

The diatom stratigraphy of the Leg 67 Pliocene/Pleistocene deposits is most complete at Site 495. The complete set of Pliocene and Pleistocene zones (Burckle, 1972 ) is present, with the exception of the uppermost beds of Pleistocene and Holocene belonging to the Coscinodiscus nodulifer Zone (Kazarina, 1978).

At Holes 499, 496, and 494A, the Pliocene is heavily disturbed, and the volume of sediments is only partly represented. Thus in Hole 499 the upper part of the Rhizosolenia praebergonii Zone (upper Pliocene) is preserved; in Hole 494A the Pliocene is represented by segments of the Nitzschia jouseae Zone (middle Pliocene); and in Hole 496 traces of the Rhizosolenia praebergonii are indistinct, and there is a sharp contact with the upper Miocene Nitzschia miocenia Zone.

In contrast to the Pliocene, the Pleistocene is represented by a very thick series of sediments reaching 200 meters, however, only at Site 495 does it have a normal sequence. The boundary beween the lower and middle to upper part of the Pleistocene, as drawn by means of diatoms, is rather distinct. 
The lower interval belongs to the Nitzschia fossilis Zone (lower Pliocene). The key assemblage contains Nitzschia reinholdii, Rhizosolenia matuyamai, and Thalassiosira leptopus var. elliptica; the lowermost parts of the zone contain Thalassiosira plicata and the silicoflagellate Mesocena elliptica .

The middle Pleistocene and the lowermost parts of the upper Pleistocene section are characterized by a mixed, ecologically heterogenous assemblage of diatoms: along with the typical oceanic and neritic species of tropical latitudes, there is a brackish-water to fresh-water assemblage of species containing Cyclotella striata. The first appearance of this species is observed at the end of the Nitzschia fossilis Zone. In some samples of Sites 499, 496, and 494 Cyclotella striata is abundant. Under present-day conditions this species inhabits nearshore waters of relatively low salinity. These areas are often upwelling zones with lower surface-water temperatures. The species, therefore, may also serve as an indicator of cool water. Cyclotella striata and accompanying numerous brackish-water and fresh-water diatoms are probably associated with turbidites. We believe that the lower boundary at which this mixed assemblage of diatoms appears can be regarded as evidence for the beginning of the maximum development of turbidity currents. Distribution of Coscinodiscus pseudoincertus in sections of Holes 494A and 496, specifically in the uppermost samples, suggests that uppermost Pleistocene and Holocene deposits are missing at these sites.

\section{ACKNOWLEDGMENTS}

We are grateful to Leg 67 participating scientists and co-chiefs Dr. R. von Huene and Dr. J. Aubouin for placing the collections of samples at our disposal.

We thank Drs. V. A. Krasheninnikov and V. N. Svalnov for revision of our manuscript, G. N., Surovtseva for translating it into English, and Irina Leonenko for technical preparation of the samples for investigation of diatoms.

Dr. Anastasia Panteleimonovna Jousé died on September 12, 1981. We deeply regret her death and applaud the high quality of the present contribution.

\section{REFERENCES}

Bukry, D., 1980. Miocene Corbisema triacantha Zone phytoplankton from Deep Sea Drilling Project Sites 415 and 416, off Northwest Africa. In Lancelot, Y., Winter, E. L., et al., Init. Repts. DSDP, 50: Washington (U.S. Govt. Printing Office), 507-523.

Burckle, L. H., 1972. Cenozoic planktonic diatoms from the eastern equatorial Pacific. Beih. Nova Hedwigia, 39:217-249.

1977. Pliocene and Pleistocene diatom datum levels from the Equatorial Pacific. Quat. Res., 7:330-340.
Burckle, L. H., Hammond, S. R., and Seyb, S. M., 1978. A stratigraphically important new diatom from the Pleistocene of the North Pacific. Pac. Sci., 32:209-214.

Burckle, L. H., and Opdyke, N., 1977. Late Neogene diatom correlations in the circum-Pacific. Proc. First Int. Congr. Pacific Neogene Stratigraphy, Tokyo, 1976, pp. 255-284.

Burckle, L. H., and Trainer, J., 1979. Middle and late Pliocene diatom datum levels from the central Pacific. Micropaleontology, 25: 281-293.

Harper, H. E., 1980. Diatom biostratigraphy of Sites 434, 435, and 436, Northwestern Pacific, Leg 56, Deep Sea Drilling Project. In von Huene, R., Nasu, N., et al., Init. Repts. DSDP, 56, 57, Pt. 2: Washington (U.S. Govt. Printing Office), 633-639.

Jousé, A. P., 1971. Diatoms in Pleistocene sediments from the northern Pacific Ocean. In Funnell, B. M., and Riedel, W. R. (Eds.): The Micropalaeontology of Oceans: Cambridge (Cambridge University Press), pp. 407-421.

1972. Diatoms in the surface sediment layer of the ChileanPeruvian region of the Pacific Ocean. Okeanologiya 12 (Moscow), (5):831-841.

Jousé, A. P., Kozlova, O. G., and Mukhina, V. V., 1971. Distribution of diatoms in the surface layer of sediment from the Pacific Ocean. In Funnell, B. M., and Riedel, W. R. (Eds.), The Micropaleontology of Oceans: Cambridge (Cambridge University Press), pp. 263-269.

Jousé, A. P., and Mukhina, V. V., 1973. Zone of Mesocena elliptica Ehr. in the Pleistocene sediments of the ocean. Okeanologiya, (Moscow), 13(6):467-475.

Kazarina, G. Kh., 1975. The diatom zones in sediment of the east part of the tropical region of the Indian Ocean. Okeanologiya (Moscow), 15(6):1073-1078.

1978. Diatoms in upper Miocene-Pleistocene sediments from the east part of the tropical region of the Indian Ocean. In Jousé, A. P. (Ed.), Marine Micropaleontology: Moscow (Nauka), pp. 3-17.

Koizumi, 1. 1975. Late Cenozoic diatom biostratigraphy in the circum-North Pacific. Geol. Soc. Jpn J., 81(10):611-627.

1977. Diatom biostratigraphy in North Pacific region. Proc. First Int. Congr. Pacific Neogene Stratigraphy, Tokyo, 1976, pp. 235-253.

Mukhina, V. V., 1971. Problems of diatom and silicoflagellate Quaternary stratigraphy in the Equatorial Pacific Ocean. In Funnell, B. M., and Riedel, W. R. (Eds.). The Micropaleontology of Oceans: Cambridge (Cambridge University Press), pp. 423-431.

, 1974. Diatoms in the suspendent matter and in the surface sediments on the shelf of southwest Africa. In Jousé, A. P. (Ed.), Micropaleontology of the Oceans and Seas: Moscow (Nauka), pp. 94-105.

Saito, T., Burckle, L. H., and Hays, I. D., 1975. Late Miocene to Pleistocene biostratigraphy of equatorial Pacific sediments. In Late Neogene Epoch Boundaries Micropaleontology Spec. Publ. 1 .

Schrader, H. J., 1974. Cenozoic marine planktonic diatom stratigraphy of the tropical Indian Ocean. In Fisher, R. L., Bunce, E. T., et al., Init. Repts. DSDP, 24: Washington (U.S. Govt. Printing Office), 887-967.

Schuette, G., and Schrader, H., 1979. Diatom taphocoenoses in the coastal upwelling area off western South America. Beih. Nova Hedwigia, 64:359-377. 


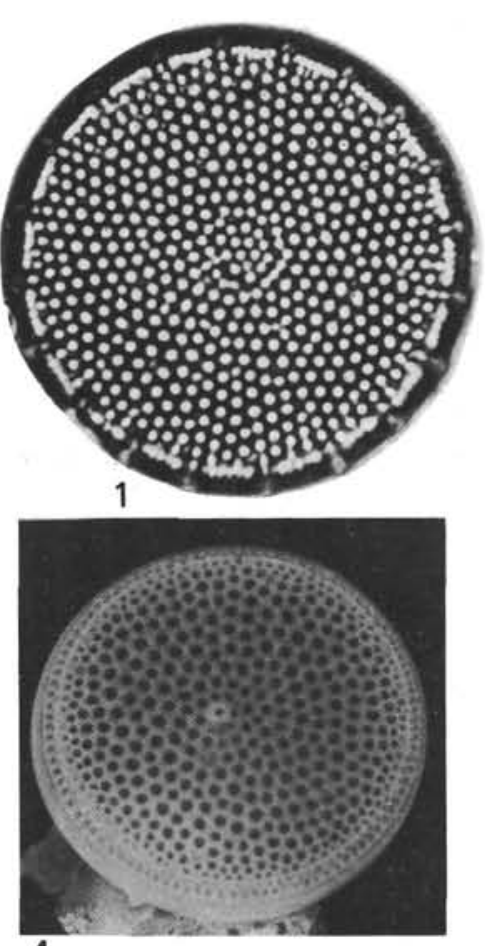

4

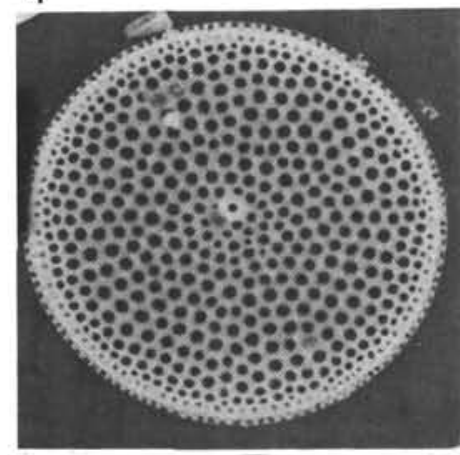

5

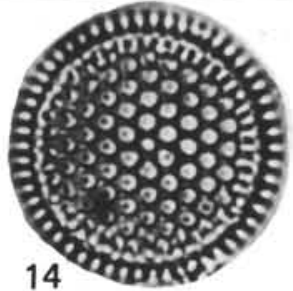

14

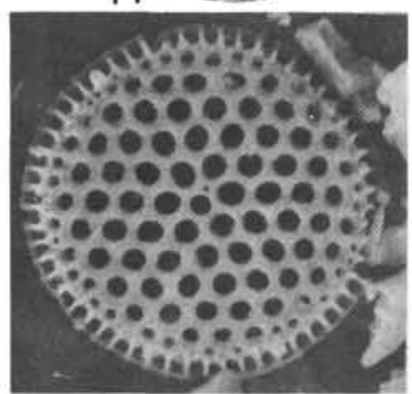

15
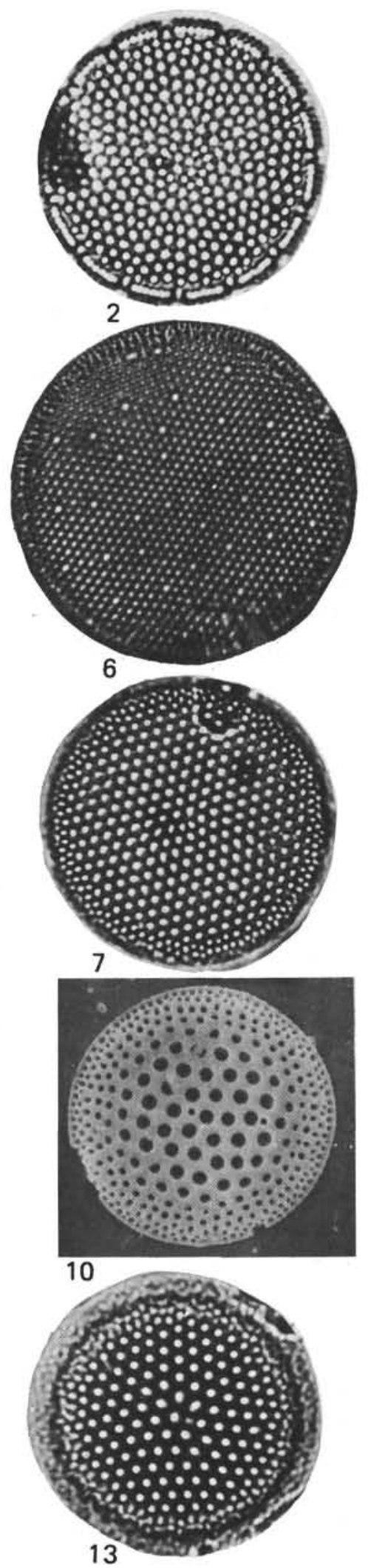

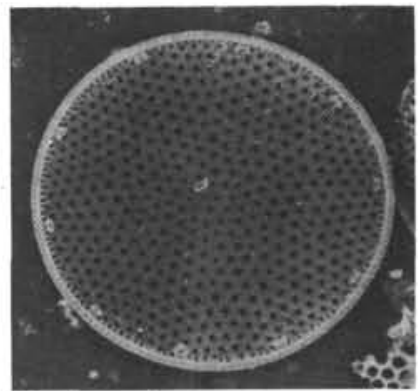

3
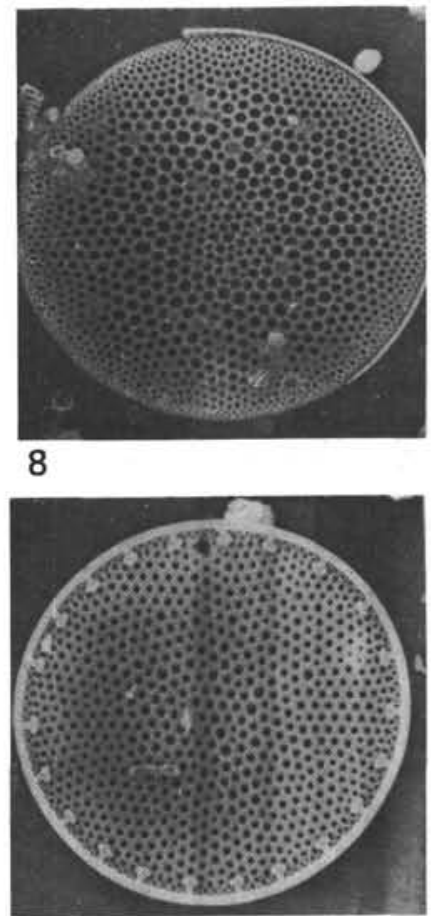

9

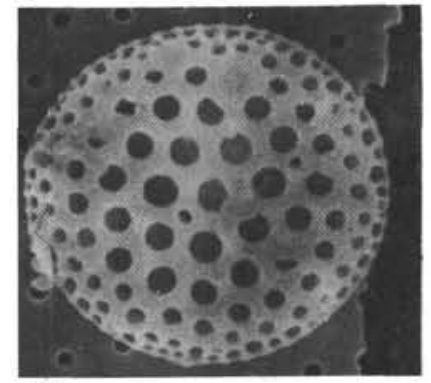

11

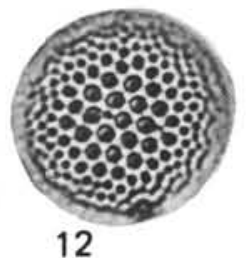

12

Plate 1. 1-3. Coscinodiscus crenulatus Grun. Sample 494A-1-2, 40-42 cm, $\times 1000$. 4-5. Coscinodiscus nodulifer A.S. Sample 496-1-1, 30-32 $\mathrm{cm}, \times 1000$. 6. Thalassiosira lineata Jousé. Sample 496-2-2, 30-32 cm, $\times 1500$. 7. Thalassiosira kozlovii Makarova. Sample 494A-1-4, 20-22 $\mathrm{cm}, \times 1000$. 8-9. Roperia tesselata (Roper) Grun. Sample 496-1-1, 30-32 cm. $\times 1000.10-13$. Thalassiosira oestrupii (Ostenf.) Pr.-Lavrenko. (10) Sample 494A-1-2, 40-42 cm, $\times 1000$. (11) Sample 496-19-3, 77-78 cm, $\times 1000$. (12-13) Sample 496-2-2, 30-32 cm, $\times 1000$. 14-15. Thalassiosira domifacta (Coscinodiscus domifactus Hendey). (14) Sample 494A-5-1, 30-32 cm, $\times 1000$. (15) Sample 494A-5-1, 30-32 cm, $\times 1500$. 

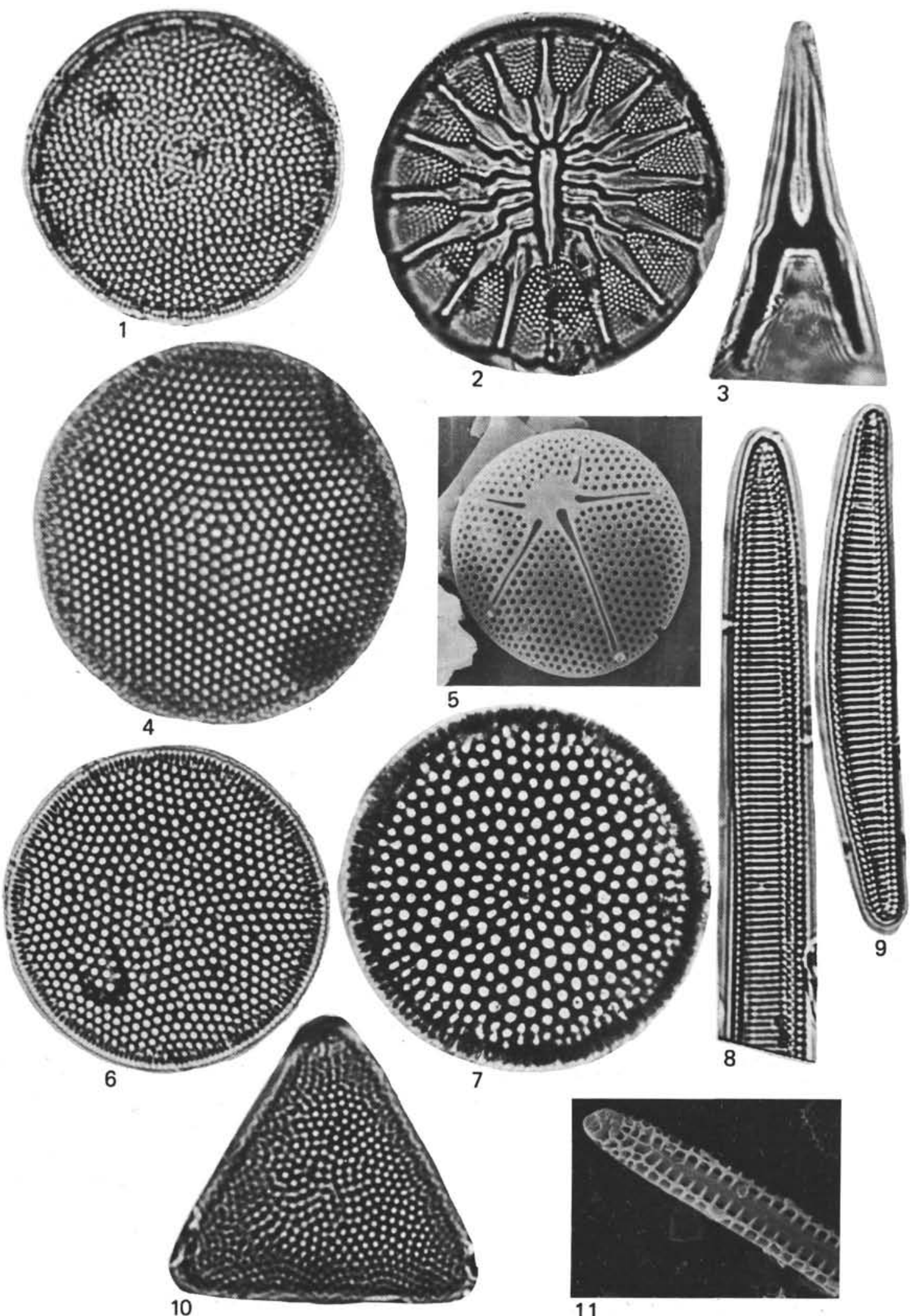

9

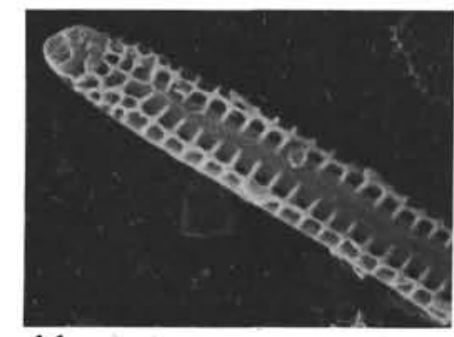

Plate 2. 1. Coscinodiscus africanus Janisch. Sample 494A-9-3, 81-83 cm, $\times 1000$. 2. Asteromphalus imbricatus Wallich. Sample 494A-1-2, 40$42 \mathrm{~cm}, \times 1000$. 3. Rhizosolenia styliformis Brightw. Sample 496-21-8, 75-77 cm, $\times 1000$. 4. Planktoniella sol (Wall.) Schutt. Sample 496-21$8,75-77 \mathrm{~cm}, \times 1500$.) 5. Asteromphalus arachne (Breb.) Ralfs. Sample 496-1-1, 30-32 cm, $\times 1000$. 6. Actinocyclus aff. curvatulus Janisch. Sample 496-15-5, 70-71 cm, $\times 1500$. 7. Coscinodiscus perforatus Ehr. Sample 496-1-3, 30-32 cm, $\times 1500$. 8. Nitzschia marina Grun. Sample 495-3-1, 75-77 cm, $\times 1500$. 9. Pseudoeunotia doliolus (Wall.) Grun. Sample $494 \mathrm{~A}-1-2,40-42 \mathrm{~cm}, \times 1500$. 10. Pseudotriceratium cinnamomeum (Grev.) Grun. Sample 494A-1-2, 40-42 cm, $\times 1500$. 11. Thalassiothrix sp. Sample 496-1-1, 30-32 cm $\times 5000$. 


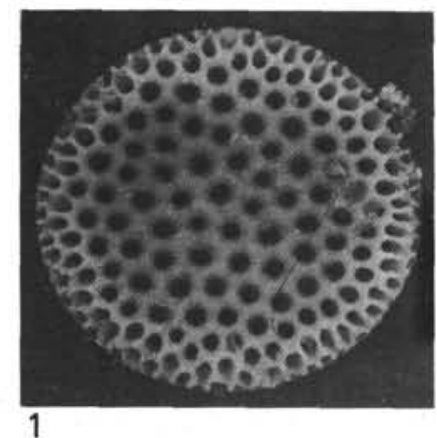

1
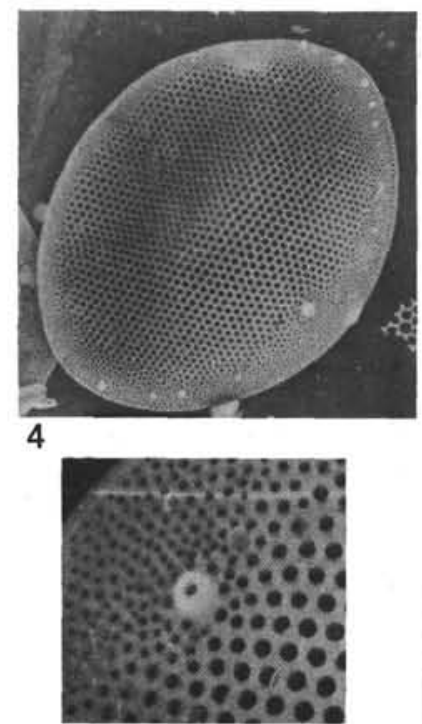

5
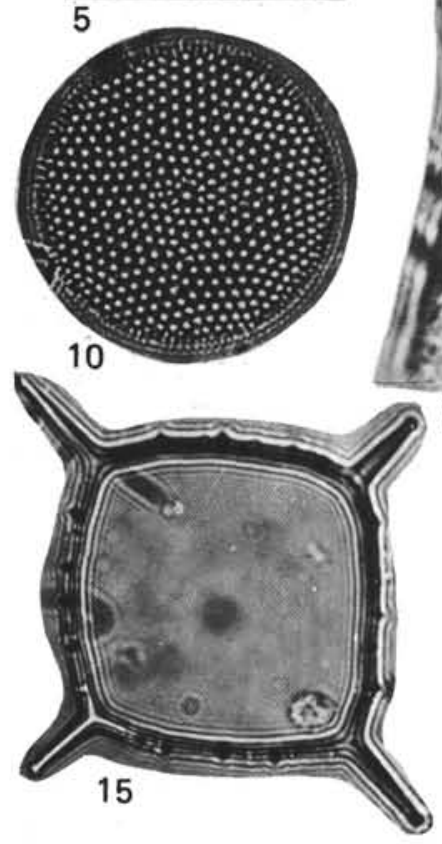

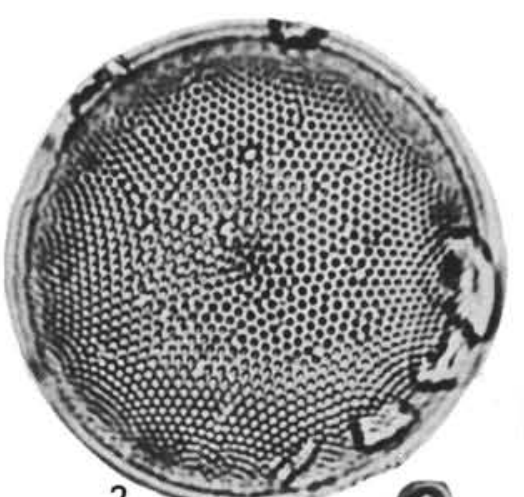

$$
2
$$
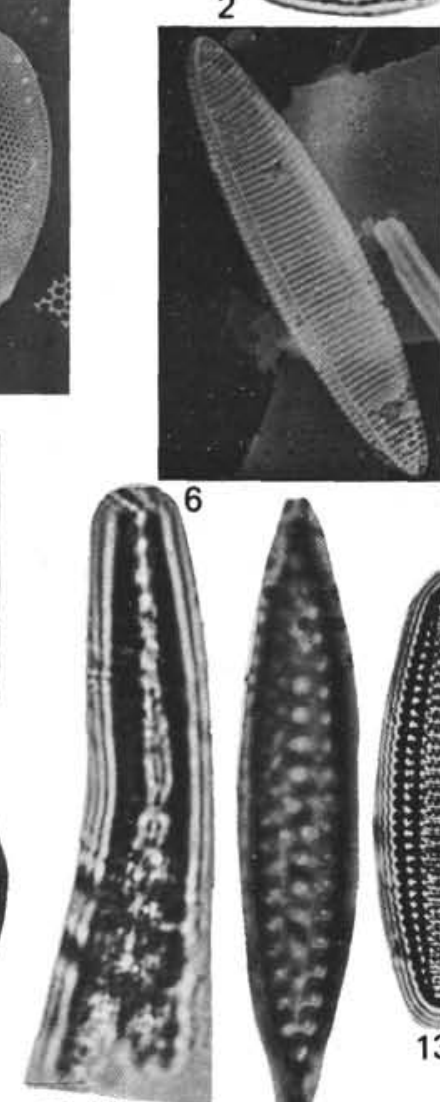

11

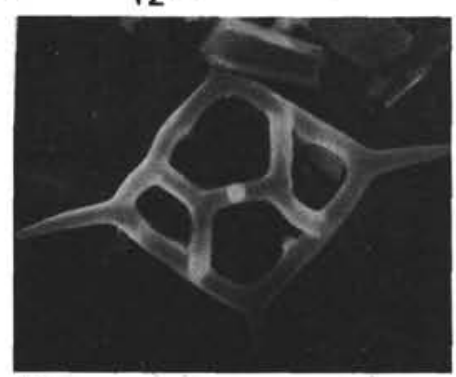

16

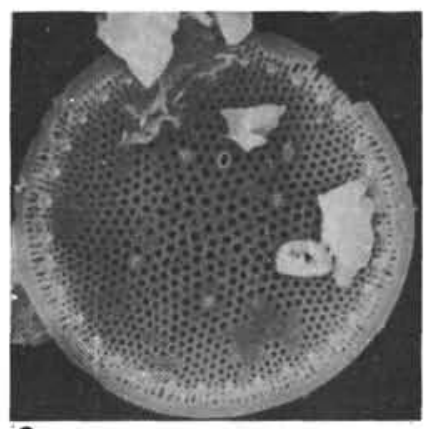

3

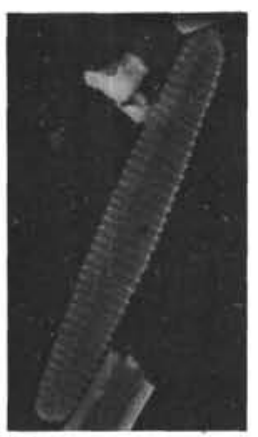

8

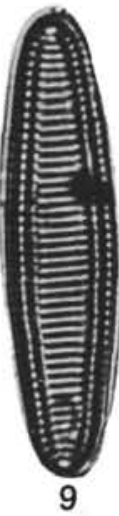

9

Plate 3. 1. Coscinodiscus pseudoincertus Kazarina. Sample 494A-1-2, 40-42 cm, $\times 1500$. 2. Thalassiosira plicata Schrader. Sample 494A-1-2, 40-42 cm, $\times 1000$. 4-5. Thalassiosira leptopus var. elliptica (Kolbe) Hasle. Sample 494A-16-1, $12-14 \mathrm{~cm}(4) \times 800 ;(5) \times 3000$. 6. Nitzschia reinholdii Kanaya and Koizumi. Sample 494A-5-1, 30-32 cm, ×1000. 7, 14. Nitzschia prolongata Kazarina. Sample 494A-16-1, 12-14 cm (7) $\times 1500$; (14) $\times 1000$. 8, 9. Nitzschia fossilis (Freng.) Kanaya. Sample 494A-17-2, 44-46 cm (8) $\times 1000 ;(9) \times 1500 . \quad 10$. Thalassiosira sp. 5 . Sample 496-3-5, 30-32 cm, $\times 1000$. 11. Rhizosolenia matuyamai Burckle. Sample 496-23-2, 43-44 cm, $\times 1000$. 12. Bogorovia mediopunctata (Hajos) Jousé. Sample 494A-20-2, 10-12 cm, $\times 2000$. 13. Nitzschia jouseae Burckle. Sample 494A-20-2, 10-12 cm, $\times 1500$. 15 . Mesocena elliptica (Ehr.) Defl. Sample 496-23-2, 43-44 cm, $\times 1500$. 16. Dictyocha fibula Ehr. Sample 496-23-2, 43-44 cm, $\times 1000.17 . \quad$ Thalassiosira convexa Mukhina. Sample 494A-20-2, 10-12 cm, $\times 1500$. 


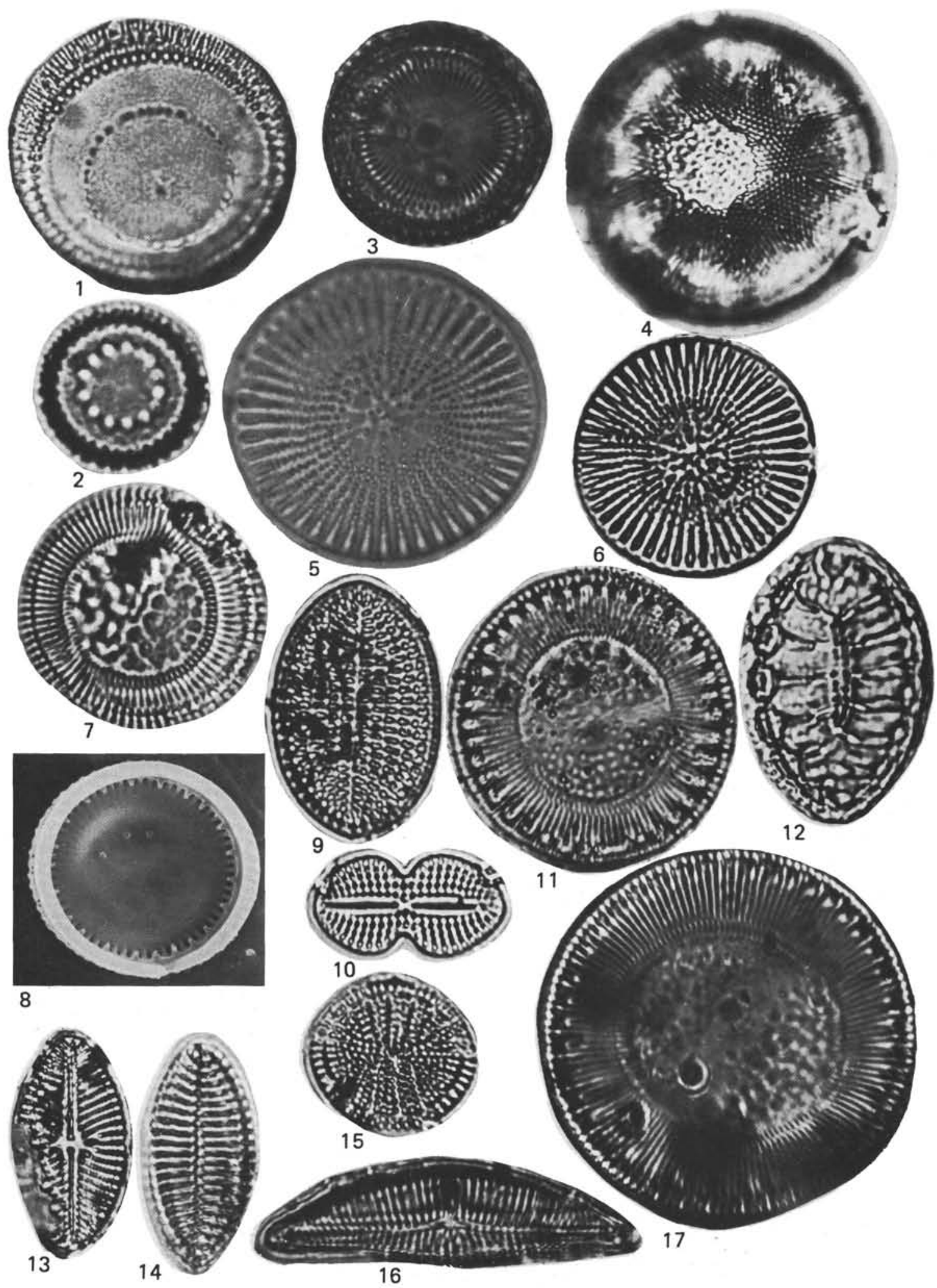

Plate 4. 1-3. Paralia sulcata (Ehr.) Ktz. (1) Sample 494A-2-6, 32-34 cm, $\times 1500$. (2) Sample 496-1-5, 30-32 cm, $\times 1000$. (3) Sample 496-11-1, 60$62 \mathrm{~cm}, \times 1000.4$. Hyalodiscus scoticus (Ktz.) Grun. Sample 494A-2-3, 36-38 cm, $\times 1500$. 5-6. Stephanodiscus sp. Sample 494A-8-1, 40-42 $\mathrm{cm}, \times 1500$. 7-8. Cyclotella striata (Ktz.) Grun. (7) Sample 494A-2-6, 32-34 cm, $\times 1500$; (8) Sample 496-8-2, 50-52 cm, $\times 1500$. 9. Cocconeis distans Greg. Sample 496-1-4, 30-32 cm, $\times 1500.10$. Diploneis bombus (Ehr.) Cleve. Sample 494A-11-1, 68-70 cm, $\times 1000.11,17$. Cyclotella stylorum Brightw. Sample 494A-1-1, 40-42 cm, $\times 1500$. 12. Surirella fastuosa (Ehr.) Ktz. Sample 494A-1-4, 20-22 cm, $\times 1500$. 13. Navicula sp. Sample 496-9-4, 40-42 cm, $\times 1000$. 14. Nitzschia sp. Sample $496-9-4,40-42 \mathrm{~cm}, \times 1000$. 15. Anorthoneis sp. Sample 496-22-3, 75-77 cm, $\times 1000$. 16. Cymbella ventricosa $\mathrm{Ktz}$. Sample 496-2-2, 30-32 cm, $\times 1000$. 

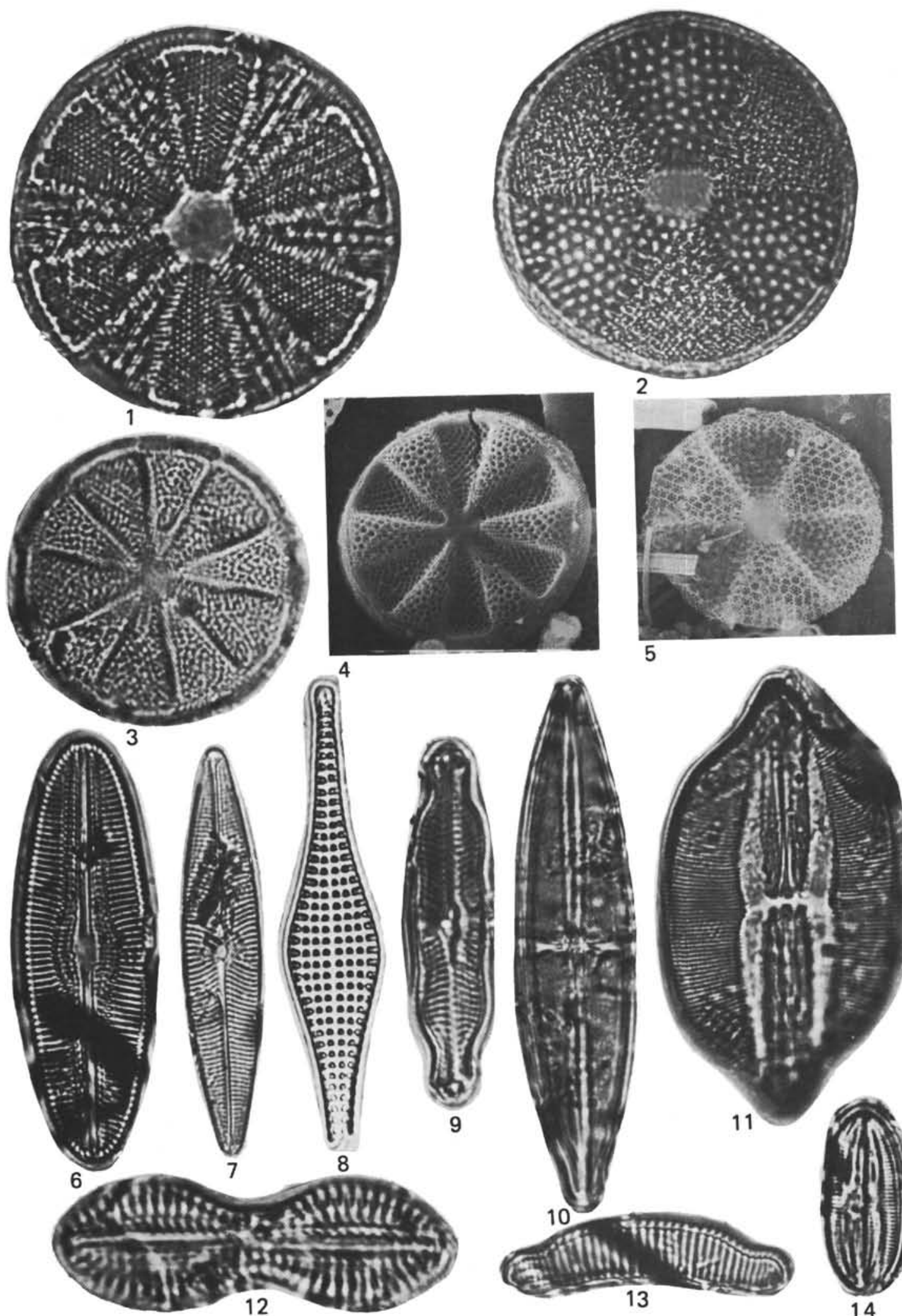

\section{5}
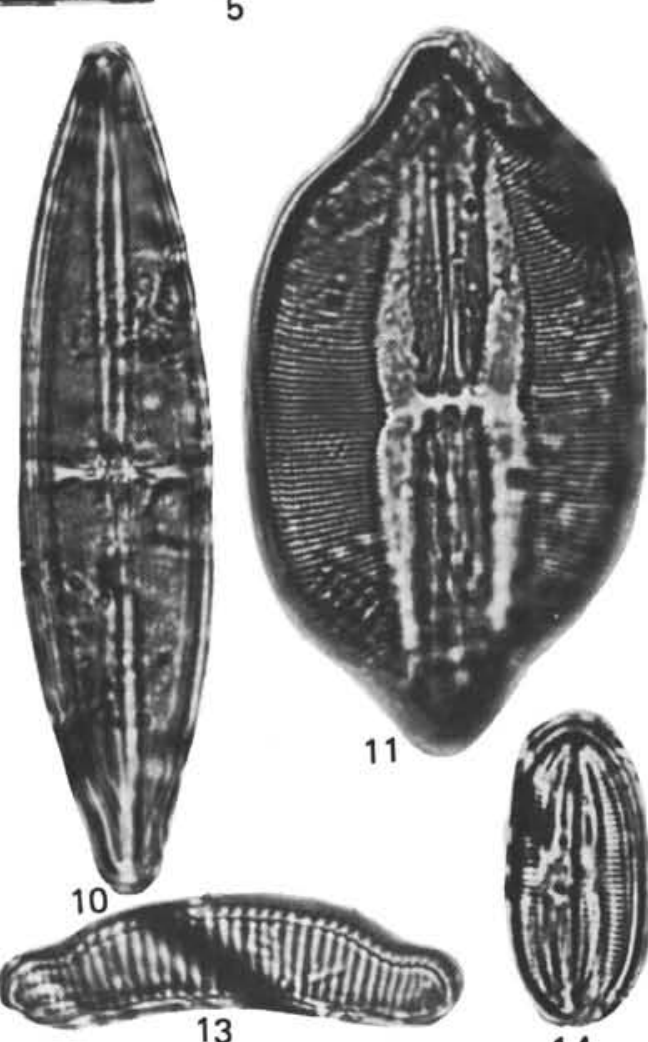

14

Plate 5. 1. Actinoptychus splendens (Shadbolt) Ralfs. Sample 496-1-4, 30-32 cm, $\times 1500.2$ 2, 5. Actinoptychus undulatus (Bail.) Ralfs. Sample 496-1-4, 30-32 cm (2) $\times 1500 ;(5) \times 1000$. 3-4. Actinoptychus bipunctatus Lohman. Sample 496-5-7, 24-26 cm, $\times 1000$. 6. Diploneis smithii (Breb.) W. Smith; DSDP 496-1-5, 30-32 cm, $\times 1000$. 7. Navicula radiosa Ktz. Sample 496-9-4, 40-42 cm, $\times 1000$. 8. Rhaphoneis amphiceros Ehr. Sample 494A-1-4, 20-22 cm, $\times 1000$. 9. Pinnularia mesolepta (Ehr.) W. Smith. Sample 496-3-2, 30-32 cm, $\times 1000$. 10. Stauroneis phoenicenteron Ehr. Sample 496-2-5, 30-32 cm, $\times 1000$. 11. Navicula clavata Greg. Sample 496-12-5, 60-62 cm, $\times 1000$. 12. Diploneis crabro Ehr. Sample 494A-1-4, 20-22 cm, $\times 1000$. 13. Eunotia septentrionalis Osetr. Sample 496-6-4, 53-37 cm, $\times 1000$. 14. Diploneis lineata (Donkin) Cleve. Sample 496-19-1, 77-78 cm, $\times 1000$. 